Tugas : individu

Mata Kuliah : Pendidikan Matematika II

Dosen Pengampuh : Jusmawati, S.Pd.,M.Pd.

\title{
RENCANA PELAKSANAAN PEMBELAJARAN
}

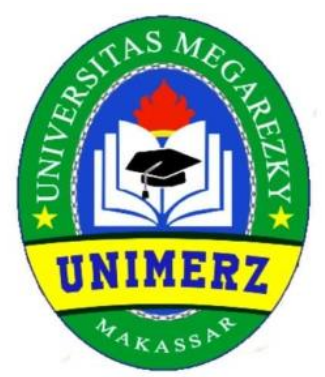

Di susun oleh:

NURSAFITRI UMAGAPI

18093188206029

PROGRAM STUDI PENDIDIKAN GURU SEKOLAH DASAR FAKULTAS KEGURUAN DAN ILMU PENDIDIKAN

UNIVERSITAS MEGAREZKY

T.A 2020/2021 


\section{KATA PENGANTAR}

Segala puji syukur penulis panjatkan kehadirat Allah SWT atas rahmat dan hidayah-Nya sehingga penulis dapat menyelesaikan Makalah dengan judul "Ringkasan Matematika Tentang Volume Limas Segi Lima”. Dalam penulisan makalah ini penulis mendapat bantuan dari semua pihak. Oleh karena itu pada kesempatan kali ini penulis ingin mengucapkan terima kasih kepada: Ibu JUSMAWATI, S.Pd.,M.Pd selaku dosen mata kuliah Matematika 2. Penulis sadar bahwa penulisan makalah ini masih jauh dari kesempurnaan, untuk itu kritik dan saran yang bersifat membangun sangat diharapkan. semoga penulisan makalah ini dapat bermanfaat bagi kita khususnya dan bagi semua pihak yang membacanya. 


\section{DAFTAR ISI}

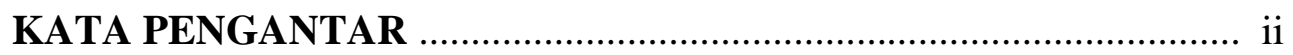

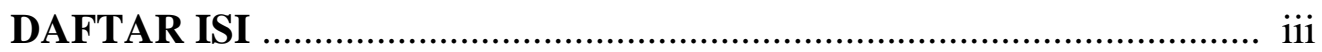

\section{BAB I PENDAHULUAN}

A. Latar Belakang ..................................................................... 4

B. Rumusan Masalah ....................................................................... 4

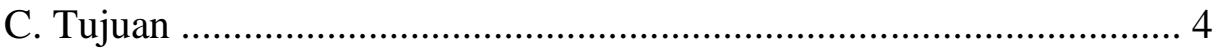

\section{BAB II PEMBAHASAN}

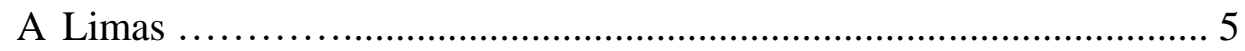

B Definisi Limas ....................................................................... 5

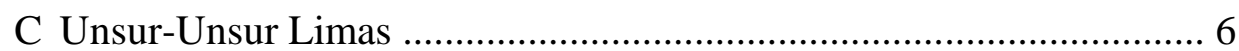

D Sifat-sifat limas ..................................................................... 7

E Ciri dan Macam-Macam Limas ....................................................... 7

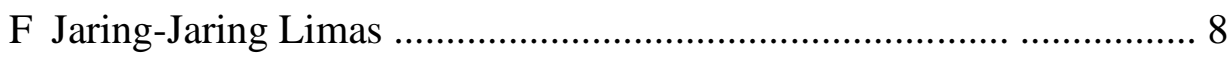

G Luas Permukaan Limas..................................................................... 8

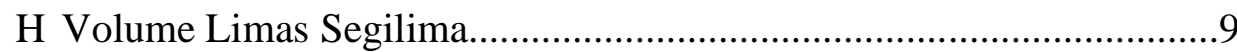

I Metode, strategi dan pendekatan............................... 10

\section{BAB III PENUTUP}

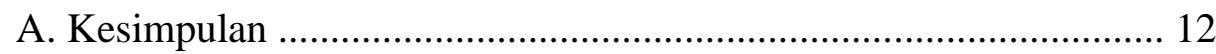

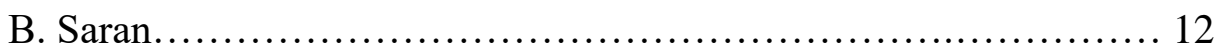

\section{DAFTAR PUSTAKA}




\section{BAB I}

\section{PENDAHULUAN}

\section{A. Latar Belakang}

Bangun ruang merupakan salah komponen matematika yang perlu kita pelajari untuk menetapkan konsep keruangan .maka dalam mata pelajaran Matematika perlu diberikan kepada semua peserta didik mulai dari sekolah dasar untuk membekali peserta didik dengan kemampuan berpikir logis, analitis, sistematis, kritis, dan kreatif, serta kemampuan bekerjasama. Kompetensi tersebut diperlukan agar peserta didik dapat memiliki kemampuan memperoleh, mengelola, dan memanfaatkan informasi untuk bertahan hidup pada keadaan yang selalu berubah, tidak pasti, dan kompetitif. Dalam makalah ini pemakalah akan menjelaskan tentang definisi, unsur-unsur, ciri-ciri, dan sifat-sifat serta macam-macam bentuk Volume Limas Segi Lima

\section{B. Rumusan Masalah}

1. Apa Limas Segi Lima?

2. Apa Definisi Limas segi lima?

3. Apa Unsur-unsur Limas Segi ?

4. Apa sifat-sifat limas?

5. Apa ciri dan macam-macam Limas?

6. Apa jarring-jaring limas ?

7. apa luas luas permukaan limas dan?

8. Apa volum Limas ?

\section{Tujuan}

1. Untuk mengetahui Limas Segi Lima

2. Untuk mengetahui Definisi Limas

3. Untuk mengetahui Unsur-unsur Limas

4. Untuk mengetahui sifat-sifat limas

5. Untuk mengetahui ciri dan macam-macam Limas segi lima

6. Untuk mengetahui jarring-jaring limas segi lima

7. Untuk mengetahui luas luas permukaan limas dan

8. Untuk mengetahui volum Limas 


\section{BAB II}

\section{PEMBAHASAN}

\section{A Pengertian Limas}

Limas adalah bangun ruang yang dibatasi oleh sebuah segi tiga ataupun segi banyak sebagai alas dan beberapa buah bidang berbentuk segitiga sebagai bidang tegak yang bertemu pada satu titik puncak. Adapaun liimas adalah bangun ruang yang alasnya berbentuk segi banyak (segitiga, segi empat, atau segi lima) dan bidang sisi tegaknya berbentuk segitiga yang berpotongan pada satu titik.

\section{B Definisi Limas Gambar limas.}

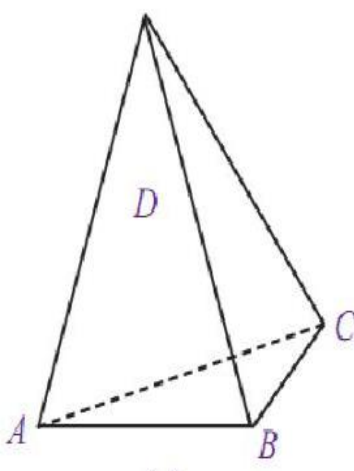

(a)

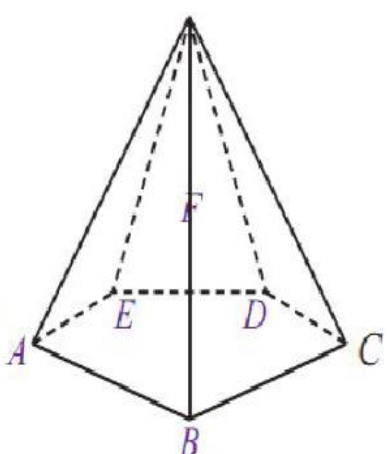

(b)

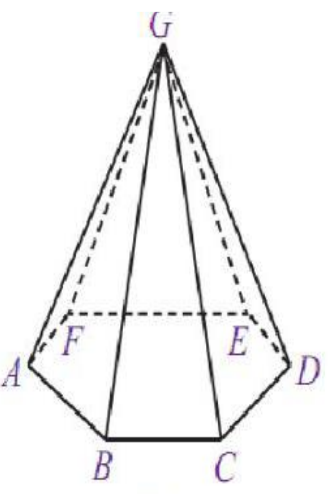

(c)

Gambar 8.29: Beberapa Limas

Limas adalah suatu bangun ruang yang dibatasi oleh sebuah segibanyak (segi-n) dan segitiga-segitiga yang mempunyai titik puncak persekutuan di luar bidang segibanyak itu. Pada gambar limas di atas, garis $\mathrm{T}$ disebut garis tinggi limas dan titik $\mathrm{T}$ disebut titik puncak limas. Garis tinggi yaitu garis yang ditarik dari titik T dan tegak lurus bidang alas ABCD. 2

\section{Unsur-Unsur Limas}


Gambar limas.

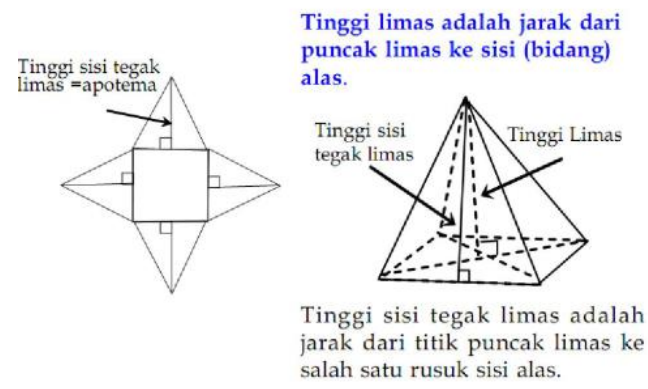

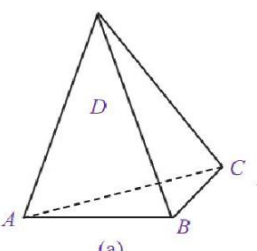

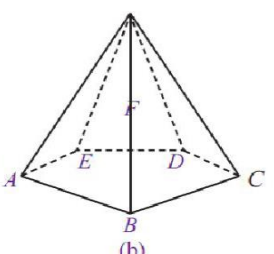

Gambar 8.29 : Beherapa Lima

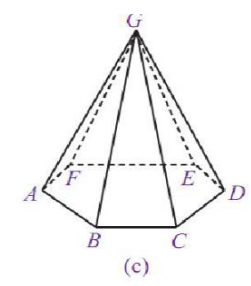

Unsur- unsur yang dimiliki oleh suatu limas:

\section{a Sisi/Bidang}

Setiap limas memiliki sisi samping yang berbentuk segitiga. Pada limas segiempat E.ABCD, sisi-sisi yang terbentuk adalah ABCD (sisi alas), $\mathrm{ABE}$ (sisi depan), DCE (sisi belakang), BCE (sisi samping kiri), dan ADE (sisi samping kanan).

b Rusuk

Perhatikan kembali limas segiempat E.ABCD Limas tersebut memiliki 4 rusuk alas dan 4 rusuk tegak. Rusuk alasnya adalah BC, CD, dan DA. Adapun rusuk tegaknya adalah AE, BE, CE, dan DE.

c Titik Sudut

Jumlah titik sudut suatu limas sangat bergantung pada bentuk alasnya.

Setiap limas memiliki titik puncak (titik yang letaknya atas). Limas 51

segitiga memiliki 4 titik sudut, limas segiempat memiliki 5 titik sudut, limas segilima memiliki 6 titik sudut, dan limas segienam memiliki 7 titik sudut

\section{Sifat-sifat Limas}



a. Bidang atas berupa sebuah titik (lancip).
b. Bidang bawah berupa bangun datar.
c. Bidang sisi tegak berupa segitiga.
d. Limas mempunyai diagonal bidang dan tidak mempunyai diagonal ruang.

\section{E Ciri dan Macam-Macam Limas}

a. Limas Segitiga T.ABC Pada gambar di samping menunjukkan limas segitiga yang mempunyai : 4 titik sudut : A, B, C, dan T 4 bidang sisi : 1 sisi alas yaitu ABC dan 3 sisi tegak yaitu TAB, TBC, dan TCA 3 rusuk alas : AB, BC, dan CA 3 rusuk tegak: AT, BT, dan CT Gambar limas segitiga.

b. Limas Segiempat T.ABCD Pada gambar di samping menunjukkan limas segiempat yang mempunyai : 5 titik sudut : A, B, C, D, dan T 5 bidang sisi : 1 sisi alas yaitu $\mathrm{ABCD}$ dan 4 sisi tegak yaitu TAB, TBC, TCD, dan TAD 4 rusuk alas : AB, BC, CD, dan DA 4 rusuk tegak: AT, BT, CT, dan DT

c. Limas Segilima T.ABCDE Pada gambar di samping menunjukkan limas segilima yang mempunyai : 6 titik sudut : A, B, C, D, E, dan T 6 bidang sisi : 1 sisi alas yaitu ABCDE dan 5 sisi tegak yaitu TAB, TBC, TCD, TDE, TAE 5 rusuk alas : AB, BC, CD, DE, dan EA 5 rusuk tegak : AT, BT, CT, DT, dan ET Gambar limas segilima.

d. Limas Segienam T.ABCDEF Pada gambar di samping menunjukkan limas segienam yang mempunyai : 7 titik sudut : A, B, C, D, E, F, dan T 7 bidang sisi : 1 sisi alas yaitu ABCDEF dan 6 sisi tegak yaitu TAB, TBC, TCD, TDE, TEF, TAF 6 rusuk alas : 6 rusuk alas yaitu AB, BC, CD, DE, EF, AF Gambar limas segienam. 6 rusuk tegak : AT, BT, CT, DT, ET, dan FT

e. Limas Segi-n Limas segi-n mempunyai:

Penamaan limas didasarkan pada jumlah segi-n sisi alasnya. Apabila alas limas berupa segi-n beraturan dan tiap sisi tegak merupakan segitiga sama kaki yang beraturan, maka limas tersebut disebut limas segi-n beraturan. Nama Limas Sisi Rusuk Titik Sudut Limas Segitiga 464 Limas Segiempat 585 Limas Segilima 6106 Limas Segienam 7127 n+1 2n n+1 Limas Segi-n 


\section{F Jaring-Jaring Limas}

Jaring-jaring merupakan bentuk dua dimensi dari suatu bangun tiga dimensi. Jaring-jaring limas dapat dibentuk dengan memotong beberapa rusuk limas. Gambar jaring-jaring limas segiempat.

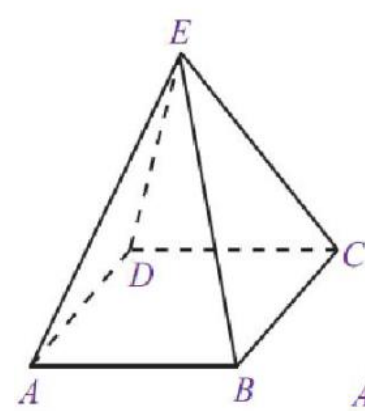

(a)

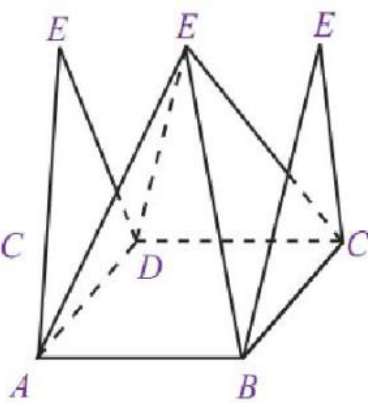

(b)

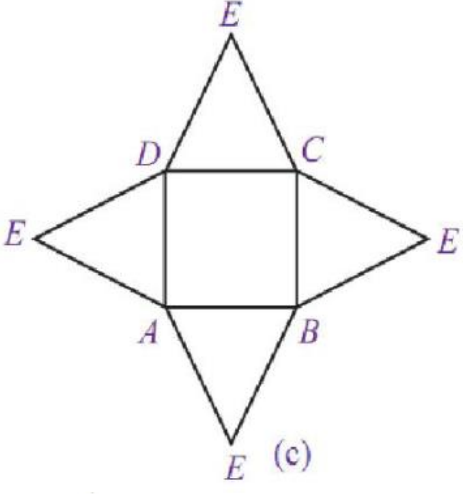

$E(c)$

\section{G Luas Permukaan Limas}

Luas permukaan menyatakan luasan permukaan suatu benda padat tiga dimensi. Luas permukaan limas dapat ditentukan dengan menjumlahkan luas sisi-sisi tegak dan luas alas. Luas permukaan limas $=$ jumlah luas sisi tegak + luas alas. Luas permukaan limas $=$ luas persegi $\mathrm{ABCD}+$ luas $\Delta \mathrm{TAB}+$ luas $\Delta \mathrm{TBC}+$ luas $\Delta \mathrm{TCD}+$ luas $\Delta \mathrm{TAD}$

Gambar 2.11
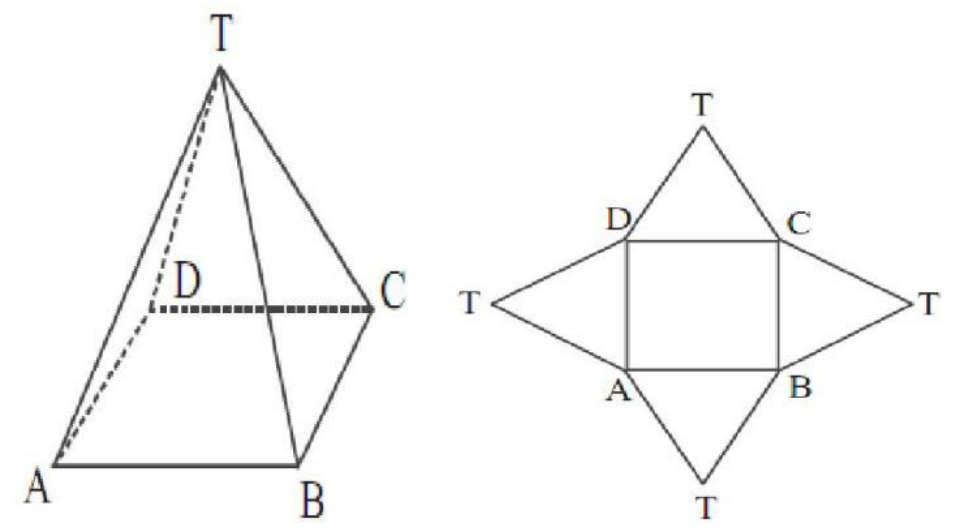

Contoh soal :

Sebuah limas segi empat beraturan, rusuk-rusuk alasnya $15 \mathrm{~cm}$ dan jarak dari puncak ke rusuk alas $20 \mathrm{~cm}$. Tentukan luas sisi limas !

Jawab :

Luas limas $=$ jumlah luas sisi tegak + luas alas Luas limas $=\left(4 \times 150 \mathrm{~cm}^{2}\right)+225 \mathrm{~cm}^{2} \mathrm{Jadi}$ luas sisi limas $825 \mathrm{~cm}^{2} .=600 \mathrm{~cm}^{2}+225 \mathrm{~cm}^{2}=825 \mathrm{~cm}^{2}$ 


\section{H Volume Limas}

Volume adalah banyak satuan volume yang memenuhi seluruh isi bangun ruang. Volume limas adalah banyaknya satuan volume yang memenuhi seluruh isi limas. Menentukan rumus volume limas dapat dihubungkan dengan kubus. Misalnya jika panjang rusuknya $2 a$ maka diperoleh hubungan berikut:

Voume limas $=\frac{1}{6} x$ volume kubus sehingga dapat rumus volume limas

yaitu volume limas $=\frac{1}{3} x$ luas alas $x$ tinggi

Volume atau bisa juga disebut kapasitas adalah penghitungan seberapa banyak ruang yang bisa ditempati dalam suatu objek. Volume limas dapat ditentukan dengan membelah sebuah kubus menjadi tiga atau enam buah limas yang kongruen.

Perhatikan Gambar 2.12 berikut ini:

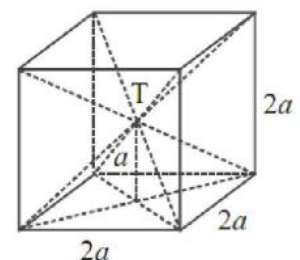

(a)

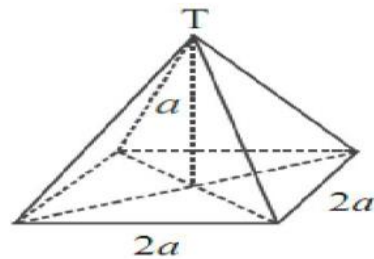

(b)

Volume limas $=1 / 3 \times$ volume kubus $=1 / 3 \times$ s x s x s $=1 / 3 \times \mathrm{s} 3=1 / 3 \times \mathrm{s}^{2} \times \mathrm{s}=1 / 3 \times$ luas alas $\mathrm{x}$ tinggi. Gambar di atas menunjukan sebuah kubus dan limas. Jika diamati secara cermat, keempat diagonal ruang tersebut membentuk 6 buah limas segiempat. Dengan demikian, volume kubus merupakan gabungan volume keenam limas tersebut. $6 \mathrm{x}$ volume limas $=$

Volume limas $=\frac{1}{6} \mathrm{x}$ volume kubus

$$
\begin{aligned}
& =\frac{1}{6} \times 2 a \times 2 a \times 2 a \\
& =\frac{1}{6} \times(2 a) \square \times 2 a \\
& =\frac{1}{3} \times(2 a) \square \times a=\frac{1}{3} \times \text { luas alas } x \text { tinggi }
\end{aligned}
$$

Oleh karena s2 merupakan luas alas kubus dan s/2 merupakan tinggi limas maka, volume limas $=1 / 3 \times$ s $2 \times s / 2=1 / 3 \times$ luas alas limas $\mathrm{x}$ tinggi limas Volume limas $=1 / 3 \times$ Luas alas $\mathrm{x}$ Tinggi 


\section{Metode, Strategis dan Pendekatan}

\section{Model Pembelajaran Jigsaw}

Model pemebelajaran kooperatif model jigsaw adalah sebuah model belajar kooperatif yang menitik beratkan kepada kerja kelompok siswa dalam bentuk kelompok kecil, seperti yang diungkapkan Lie ( 1993: 73), bahwa pembelajaran kooperatif model jigsaw ini merupakan model belajar kooperatif dengan cara siswa belajar dalam kelompok kecil yang terdiri atas empat sampai dengan enam orang secara heterogen dan siswa bekerja sama salaing ketergantungan positif dan bertanggung jawab secara mandiri.

Kompetensi dan tujuan pembelajaran akan tercapai secara optimal apabila pemilihan, metode, strategi, dan model-model pembelajaran tepat dan disesuaikan dengan materi, tingkat kemampuan siswa, karakter siswa, kemampuan sarana dan prasarana dan kemampuan guru dalam menerapkan secara tepat guna pendekatan, metode, strategi dan model-model pembelajaran.

Metode dapat di artikan secara teratur yang di gunakan untuk melaksanakan pembelajaran. menurut sanjaya (2009:127) metode adalah cara yang dapat di gunakan untuk melaksanakan strategi.

Metode pembelajaran adalah cara kerja yang sistem untuk memudahkan pelaksanaan pembelajaran sehingga kompetensi dan tujuan pembelajaran dapat tercapai. Jadi metode pembelajaran dapat di simpukan adalah hal yang menyangkut cara seseorang guru dalam menyampaikan atau menyajikan bahan pelajaran siswa dalam proses belajar mengajar sehingga cara tersebut bisa mencapai tujuan pembelajaran.

1. Exposition discovery learning

- Strategi penyampaian atau ekspository, yaitu strategi pembelajaran langsung dengan menyajikan materi pelajaran yang sudah jadi dan siswa diharapkan menguasai secara penuh. Strategi ekspository menempatkan guru sebagai penyampai materi

- Discovery learning, yaitu ssiswa mencari dan menemukan materi pelajaran sendiri melalui berbagai aktivitas. Tugas guru sebagai fasilotator dan membimbing siswa dalam pembelajaran (strategi tidak langsung)

1. Strategi group individual learning 
Perancangan aktivitas belajar mandiri bagi siswa untuk menentukan kemampuan individu dan tingkat kecepatan keberhasilan penguasaan materi pembelajaran. Strategi pembelajaran ditinjau dari cara menyajikan materi dapat dibagi menjadi dua yaitu :

- Strategi pembelajaran deduktif, yang berupaya untuk menyajikan materi dari umum ke khusus, atau dimulai dari hal-hal yang abstrak menuju hal-hal yang konkret

- Strategi pembelajaran induktif, menyajikan materi yang konkret selanjutnya diarahkan pada materi yang kompleks, aatau dimulai dari hal khusus menuju hal yang umum. 


\section{BAB III}

\section{PENUTUP}

\section{A. Kesimpulan}

Dari isi makalah yaitu : Bangun ruang adalah bangun matematika yang mempunyai isi ataupun volume. Bangun limas segi lima memiliki enam sisi. Enam sisi tersebut termasuk satu sisi alas dan lima sisi tegak limas. Sisi alas berupa bangun datar segi lima dan sisi tegak berupa bangun segitiga. Titik sudut: titik hasil pertemuan rusuk yang berjumlah tiga atau lebih. Jenisjenis bangun ruang yang umum dikenal dan saat ini kita pelajari adalah: Volume Limas segi lima. Bangun segi lima merupakan bangun datar yang dibatasi oleh lima sisi.

\section{B. Saran}

Guru dapat menggunakan metode yang tepat untuk menyampaikan materi. Pada materi volume limas guru dapat menggunakan alat peraga untuk membantu siswa melihat hubungan antara volume limas persegi lima dan volume kubus. Sebelum melakukan penilitian selanjutnya dapat melakukan observasi terhadap guru supaya dapat melihat karakteristik siswa yang akan menjadi subjek penilitian. 


\section{DAFTAR PUSTAKA}

Djumanta Wahyudin \& Susanti Dwi. (2008). Belajar Matematika Aktif dan Menyenangkan. Jakarta: PT Setia Purna Inves

http://yos3prens.wordpress.com/2013/02/19/menemukan-luas-permukaanlimasberaturan/,

http://id.wikipedia.org/wiki/Luas, diakses tanggal 21 Desember 2013 pukul 10.38

http://nanangmatematikastema.blogspot.com/2011/05/alat-peraga-matematikadisusunoleh.html, diakses tanggal 24 Desember 2013 pukul 21.01 


\section{RENCANA PELAKSANAAN PEMBELAJARAN}

(RPP)

$\begin{array}{ll}\text { Satuan Pendidikan } & \text { : SDN } 21 \text { Sungai Kakap } \\ \text { Kelas / Semester } & : \text { V / II } \\ \text { Mata Pelajaran } & : \text { Matematika } \\ \text { Materi Pembelajaran } & : \text { Volume Limas segilima } \\ \text { Pertemuan } & : 1 \times \text { pertemuan } \\ \text { Alokasi waktu } & : 2 \times 35 \text { menit }\end{array}$

\section{A Standar kompetensi}

1. Memahami sifat-sifat volume limas segilima dan hubungan antar volume limas segilima

\section{B Kompetensi Dasar}

1. Menyelesaikan masalah yang berkaitan dengan volume limas segilima dan volume limas segilima yang sederhana

\section{Indikator}

1. Menemukan cara menurunkan rumus volume limas segilima

2. Menerapkan rumus untuk menghitung volume limas segilima

3. siswa dapat menemukan rumus luas permukaan limas segilima

4. siswa dapat menemukan rumus volume limas segilima

\section{Tujuan Pembelajaran}

1. Setelah menyimak penjelasan tentang unsur-unsur limas, siswa dapat mengambar kerangka limas segilima 
2. Setelah melakukan demonstrasi peragaan, siswa dapat menuliskan proses menemukan rumus limas.

3. Setelah menyimak penjelasan contoh soal, dan Tanya jawab, siswa dapat menerapkan rumus, untuk menghitung volume limas segilima.

\section{E. Materi Pembelajaran}

Menemukan Rumus Volume Limas

Langkah-langkah menemukan rumus volume limas :

1. Menyiapkan model bangun ruang berbentuk limas segi lima, dengan ukuran alas dan tinggi yang sama.

2. Isilah limas dengan pasir atau beras sampai penuh,

Setelah melakukan praktik, lengkapilah isian di bawah ini!

- Volume limas segilima adalah $1 / 3$ kali volume limas.

- Maka, volume limas : $1 / 3 \times$ volume prisma $=1 / 3 \times$ LA $x \mathrm{t}$

Jadi, rumus volume limas segilima $=1 / 3 \times$ LA $\times \mathrm{t}$

Contoh soal:

1. Tinggi $=7 \mathrm{~cm}$

Panjang alas $=4 \mathrm{~cm}$

Hitunglah volumenya!

Jawab : Volume limas segilima $=1 / 3 \times$ LA $x \mathrm{t}$

Maka $=1 / 3 \times 4 \mathrm{~cm} \times 7 \mathrm{~cm}$

$=1 / 3 \times 28 \mathrm{~cm}$

$=28 / 3 \mathrm{~cm}$

$=9,33 \mathrm{~cm} 3$ 
2. Sebuah botol parfum berbentuk limas, dengan tinggi $15 \mathrm{~cm}$, dan alas berbentuk persegi dengan ukuran $7 \mathrm{~cm}$. Hitunglah berapa volume botol parfum tersebut!

Jawab: Diketahui : Tinggi botol $=15 \mathrm{~cm}$

Ukuran alas $=7 \mathrm{~cm}$

Ditanya $=$ Volume botol $?$

Maka : Volume limas sgilima $=1 / 3 \times$ LA $\times \mathrm{t}=1 / 3 \times 7 \mathrm{~cm} \times 15 \mathrm{~cm}=1 / 3 \times 105 \mathrm{~cm}=$ $105 / 3=35 \mathrm{~cm} 3$

Jadi, volume botol parfum adalah, $35 \mathrm{~cm} 3$.

3. Sebuah bangun berbentuk limas segilima dengan alas berbentuk persegi dengan sisinya

$15 \mathrm{~cm}$. Tentukan volume limas tersebut apabila tingginya $30 \mathrm{~cm}$ !

Pembahasannya:

Diketahui : sisi alas $(\mathrm{s})=15 \mathrm{~cm}$

tinggi limas $(\mathrm{t})=30 \mathrm{~cm}$

Ditanya : volume limas segilima

Jawab :

$\mathrm{v}=\left(1 / 3 \times\right.$ Luas Alas $\mathrm{xt}=1 / 3 \times 15 \times 1530=2250 \mathrm{~cm}^{3}$

Maka, volume limas segilima tersebut ialah: $2250 \mathrm{~cm}^{3}$

\section{F. Metode Pembelajaran}

- Pendekatan : saintifik

- Metode : Tanya Jawab, Penugasan, Demonstrasi, discovery learning

- Model : Pembelajaran kooperatif

G. Langkah- langkah Pembelajaran 


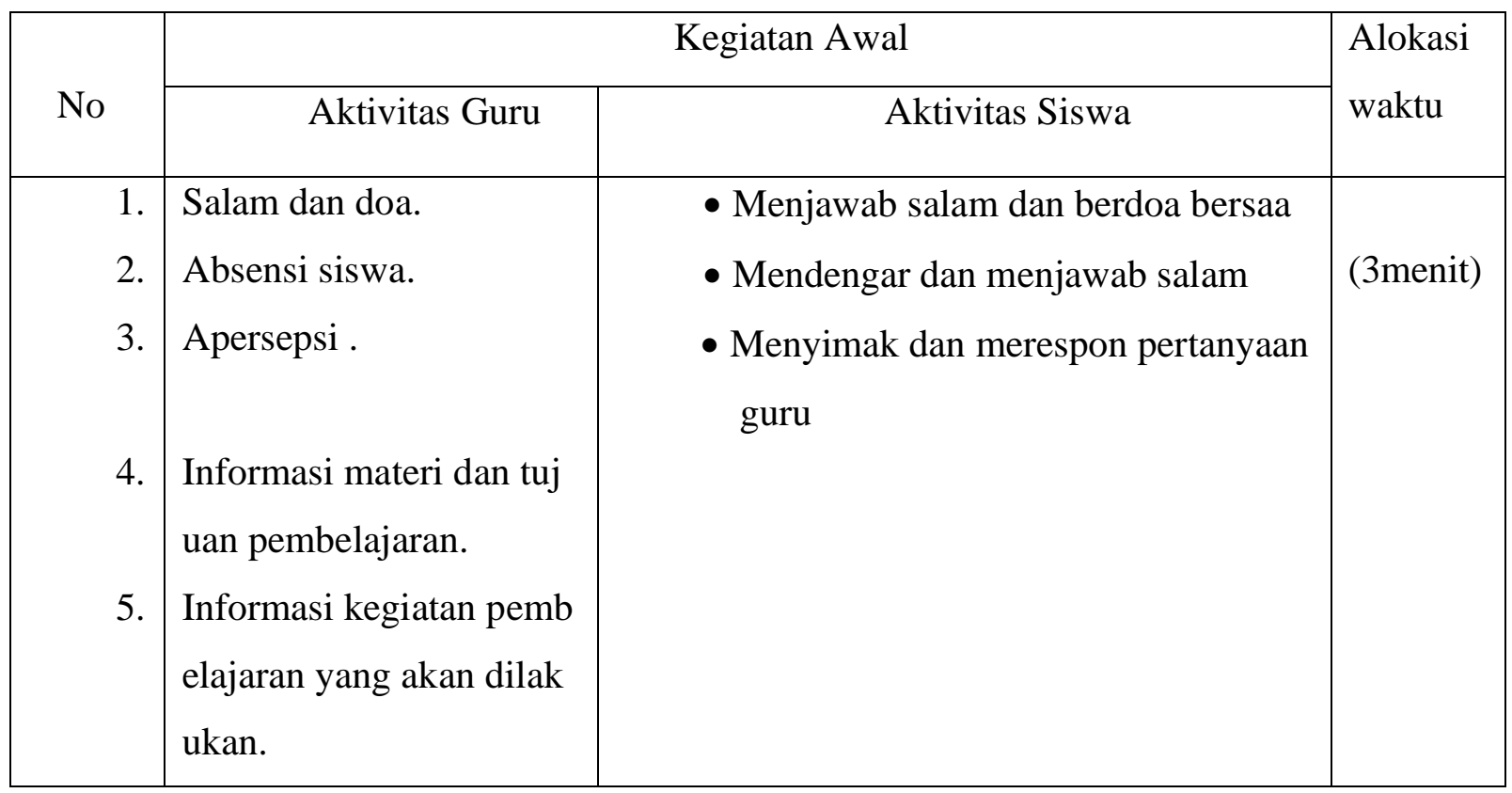

\begin{tabular}{|c|c|c|c|}
\hline \multirow[b]{2}{*}{ No } & \multicolumn{2}{|c|}{ Kegiatan Inti } & \multirow[b]{2}{*}{$\begin{array}{l}\text { Alokasi } \\
\text { Waktu }\end{array}$} \\
\hline & Aktivitas Guru & Aktivitas Siswa & \\
\hline 1. & $\begin{array}{l}\text { Guru membimbing siswa mengam } \\
\text { bar kerangka limas segi empat }\end{array}$ & $\begin{array}{l}\text { - } \text { Tanya jawab dengan si } \\
\text { swa tentang kerangka } \\
\text { limas segi empat terben }\end{array}$ & (25menit) \\
\hline 2. & $\begin{array}{l}\text { Guru membimbing siswa membuat } \\
\text { jaring-jaring limas. }\end{array}$ & $\begin{array}{l}\text { tuk . } \\
\text { - Siswa melakukan pera } \\
\text { gaan untuk menemuka }\end{array}$ & \\
\hline 3. & $\begin{array}{l}\text { Guru melatih dan membimbing siswa } \\
\text { dengan peragaan untuk menggunting ja } \\
\text { ring-jaring limas segi lima }\end{array}$ & $\begin{array}{l}\text { n cara menurunkan ru } \\
\text { mus volume limas den } \\
\text { gan dibimbing oleh gur }\end{array}$ & \\
\hline 4. & $\begin{array}{l}\text { Guru dan siswa membahas contoh soal } \\
\text { secara bersama-sama }\end{array}$ & $\begin{array}{l}\text { u. } \\
\text { - Siswa menerapkan rum }\end{array}$ & \\
\hline 6. & $\begin{array}{l}\text { Guru dan siswa melakukan Tanya jawab } \\
\text { mengenai materi pelajaran }\end{array}$ & $\begin{array}{l}\text { us untuk menghitung } \\
\text { volume limas, melalui } \\
\text { pemberian contoh cooh } \\
\text { soal }\end{array}$ & \\
\hline
\end{tabular}




\begin{tabular}{|l|l|l|}
\hline Guru mengawasi atau membimbing & Siswa menyimpulkan \\
siswa dalam mengerjakan soal. & materi pelajaran denga \\
& n dibimbing oleh guru. \\
& - Siswa mengerjakan \\
& secara individu \\
& Pelaporan dan pembah \\
& & \\
\hline
\end{tabular}

\begin{tabular}{|l|l|l|l|}
\hline \multirow{3}{*}{ No } & \multicolumn{1}{|c|}{ Kegiatan Penutup } & \multirow{2}{|c|}{ Alokasi } \\
\cline { 2 - 4 } & \multicolumn{1}{|c|}{ Aktivitas Guru } & Aktivitas Siswa & Waktu \\
\hline 1. & $\begin{array}{l}\text { Guru bersama siswa mengadakan refleksi } \\
\text { terhadap kegiatan pembelajaran } \\
\text { 2. }\end{array}$ & $\begin{array}{l}\text { Guru bersama siswa merangkum materi } \\
\text { pelajaran } \\
\text { Guru melaksanakan penilaian akhir Guru } \\
\text { mengadakan tindak lanjut } \\
\text { Guru Menutup pelajaran }\end{array}$ & (7 menit) \\
\hline
\end{tabular}

H. Media/alat peraga

Media/Alat Peraga

A. Bahan ; Kertas origami; plastik keras

B. Alat: 1.Gunting

2. Lem

\section{Penilaian}


1. Teknik: Tes

2. Prosedur

Penilaian hasil : Kemampuan siswa menyelesaikan soal akhir pembelajaran

a Jenis tes : Tulisan

b Bentuk tes : Essay

\section{J. Instrumen Penilaian}

Selesaikan Soal berikut dengan menulis apa yang diketahui, yang ditanya dan penyelesiaan:

1. Alas sebuah limas beraturan berbentuk persegi dengan panjang sisi $18 \mathrm{~cm}$. Tinggi segitiga pada bidang tegaknya $15 \mathrm{~cm}$. Volume limas tersebut adalah ...

2. Alas sebuah limas berbentuk persegi yang panjangnya $10 \mathrm{~cm}$ dantinggi segitiga pada sisi tegaknya adalah $13 \mathrm{~cm}$.

Hitunglah tinggi limas dan luas limas!

Kunci Jawaban

1. volume limas $\quad=1 / 3 \times$ LA $\times \mathrm{t}$

$$
\begin{aligned}
& =1 / 3 \times 10 \times 13 \\
& =1 / 3 \times 130 \\
& =43,3 \mathrm{~cm} 3
\end{aligned}
$$

2. Tinggi $=12 \mathrm{~cm}$.

$$
\begin{aligned}
\text { Luas limas } & =s^{2}+2 a t \\
& =10^{2}+2.10 .12 \\
& =100+240 \\
& =340 \mathrm{~cm} 2
\end{aligned}
$$


Jadi, luas limas segilima adalah $340 \mathrm{~cm} 2$

\section{K. Pedoman penskoran/penilaian}

Soal no. 1

\begin{tabular}{|r|l|c|}
\hline \multicolumn{1}{|l|}{ No } & \multicolumn{1}{|c|}{ Indikator } & Skor \\
\hline 1 & Menuliskan apa yang diketahui, jika benar & 7 \\
\hline 2 & Menuliskan apa yang ditanyakan, jika benar & 3 \\
\hline 3 & Menjawab penyelesaian soal benar & 15 \\
\hline & Jumlah skor & 25 \\
\hline
\end{tabular}

Soal No. 2

\begin{tabular}{|c|l|c|}
\hline No & \multicolumn{1}{|l|}{ Indikator } & Skor \\
\hline 1 & Menuliskan apa yang diketahui, jika benar & 7 \\
\hline 2 & Menuliskan apa yang ditanyakan, jika benar & 3 \\
\hline 3 & Menjawab penyelesaian soal benar & 20 \\
\hline & Jumlah skor & 30 \\
\hline
\end{tabular}


